DedikasiMU (Journal of Community Service)

Volume 3, Nomor 3, September 2021

\title{
EDUKASI VIRUS COVID-19 SERTA PNGENALAN LITERASI KEUANGAN MELALUI PROGRAM KKN UNTUK MEWUJUDKAN DESA KEDUNGRUKEM SIGAP, CERDAS DAN SEHAT
}

\author{
Hilda Rodhotul Ainiyah ${ }^{1}$, Andi Rahmad Rahim² ${ }^{2}$ Sukaris $^{3}$, Ernawati $^{4}$ \\ ${ }^{1}$ Mahasiswa Program Studi Akuntansi, Universitas Muhammadiyah Gresik \\ ${ }^{2}$ Dosen Budidaya Perikanan, Universitas Muhammadiyah Gresik \\ ${ }^{3}$ Dosen Manajemen, Universitas Muhammadiyah Gresik \\ ${ }^{4}$ Dosen Ilmu Keperawatan, Universitas Muhammadiyah Gresik \\ Email : hildaarodhotul@gmail.com
}

\begin{abstract}
ABSTRAK
Corona virus Disease-2019 (COVID-19) diketahui menyebabkan infeksi saluran nafas pada manusia mulai dari batuk pilek hingga yang lebih serius seperti Middle East Respiratory Syndrome (MERS) dan Severe Acute Respiratory Syndrome (SARS). Persebaran virus COVID-19 meningkat semakin cepat melalui tetesan air liur atau keluar dari hidung ketika orang yang terinfeksi batuk atau bersin. Akan tetapi, masih sangat minim pemahaman dan kesadaran masyarakat di Desa Kedungrukem Kecamatan Benjeng Kabupaten Gresik yang mematuhi protokol kesehatan saat beraktivitas di luar rumah. Lokasi tersebut merupakan padat penduduk. Oleh karena itu, perlunya peningkatan pemahaman COVID-19 dan pentingnya mematuhi protokol kesehatan penanggulangan COVID-19. Berdasakan permasalahan tersebut, penulis melakukan pengabdian pada masyarakat melalui kegiatan Kuliah Kerja Nyata (KKN) UMG Era Covid-19. Kegiatan yang dilakukan dengan metode Edukasi COVID19 secara online Kepada Masyarakat Desa Kedungrukem. Pada program KKN ini dilakukan pembagian masker, pembagian banner tentang bahaya dan cara pencegahan COVID19, edukasi tentang pentingnya menabung dimasa Pandemi COVID19, pembuatan pembukuan laporan keuangan untuk Karangtaruna Dusun Bulak Ploso serta edukasi protokol kesehatan di lingkungan Desa Kedungrukem secara virtual. Telah berhasil disalurkan sebanyak 75 masker, 1 banner tentang bahaya dan cara pencegahan COVID19, video edukasi tentang menabung dan cara pencegahan COVID19.
\end{abstract}

Kata Kunci: COVID-19, KKN, Edukasi 


\section{DedikasiMU (Journal of Community Service)}

Volume 3, Nomor 3, September 2021

\section{PENDAHULUAN}

\section{A. Latar Belakang}

Coronavirus adalah suatu kelompok virus yang dapat menyebabkan penyakit pada hewan atau manusia. Beberapa jenis coronavirus diketahui menyebabkan infeksi saluran nafas pada manusia mulai dari batuk pilek hingga yang lebih serius seperti Middle East Respiratory Syndrome (MERS) dan Severe Acute Respiratory Syndrome (SARS) (Guan, dkk 2020). Coronavirus jenis baru yang ditemukan menyebabkan penyakit COVID-19 (WHO, 2020). Hingga kini laju persebaran Corona virus Disease-2019 (COVID-19) meningkat semakin cepat cepat melalui tetesan air liur atau keluar dari hidung ketika orang yang terinfeksi batuk atau bersin.

Upaya pemerintah dalam menanggulangi penyebaran COVID-19 yang sangat cepat ini sudah mencakup banyak aspek kehidupan. Di bidang pendidikan, pemerintah menerapkan pelaksanaan program belajar di rumah (Kemendikbud, 2020). Hal ini bisa melalui berbagai media berbasis internet maupun melalui media yang tidak berbasis internet (Darmalaksana, dkk 2020). Di bidang sosial masyarakat, pemerintah dengan gencar mencanangkan konsep mitigasi komunitas, berupa pengurangan frekuensi pertemuan besar, pembatasan jarak antar orang di fasilitas umum, hingga penerapan konsep aktivitas yang lebih baik dilaksanakan di rumah (Yunus, dkk 2020). Di bidang kesehatan, pemerintah telah dengan gencarnya mengedukasi masyarakat terkait pentingnya hidup bersih dan sehat, perlunya mengenakan masker saat di luar rumah, pelaksanaan karantina mandiri untuk orang-orang yang memiliki risiko tinggi, serta berbagai pedoman yang bertujuan untuk mencegah penularan COVID-19 (Telaumbanua, 2020). Di bidang agama pun, pemerintah melalui Majelis Ulama Indonesia (MUI) telah memberikan fatwa terkait dengan pelaksanaan ibadah di masa wabah pandemi COVID-19 (MUI, 2020). Hingga pada tingkat desa, pemerintah telah mengeluarkan protokol terkait Relawan Desa Lawan COVID-19 (Kemendesa, 2020). 


\section{DedikasiMU (Journal of Community Service)}

Volume 3, Nomor 3, September 2021

Namun, meskipun pemerintah telah melakukan berbagai upaya dalam menanggulangi penyebaran COVID-19, penambahan kasus positif COVID-19 di Indonesia semakin bertambah. Hal ini disebabkan karena kurangnya pengetahuan terhadap pandemi yang berimplikasi terhadap minimnya kesadaran masyarakat sehingga penanganan (pencegahan bagi yang tidak terinfeksi dan atau pengobatan terhadap yang terkena wabah) kurang terintegrasi-interkoneksi dalam sistem pemerintahan di negara kita. Dari pusat sampai bagian paling bawah, yaitu desa (kampung). Hal ini sangat berbahaya karena penyebaran COVID-19 sangat rentan tertular melalui mata, hidung, dan mulut (WHO, 2020).

Desa Kedungrukem Kecamatan Benjeng Kabupaten Gresik merupakan tempat tinggal padat penduduk. Lokasi tersebut sering dilalui orang-orang yang berasal dari daerah luar karena dekat dengan jalan raya. Hal ini menjadi rawan akan terjadinya penyebaran COVID-19 apabila tidak adanya pemahaman dan protokol kesahatan dalam penanggulangan COVID-19 (Shodiqin, dkk 2020).

Sebagai salah satu civitas akademika yang memiliki tugas Tri Dharma Perguruan Tinggi terpanggil untuk turut berkontribusi bersama dalam menghadapi COVID-19 (Syahrian, 2020). Dengan melihat situasi Desa Kedungrukem Kecamatan Benjeng Kabupaten Gresik, kami melakukan kegiatan pengabdian kepada masyarakat dalam bentuk kegiatan Kuliah Kerja Nyata (KKN) UMG Era COVID-19 dengan tema Pencegahan Covid19 untuk Mewujudkan Kehidupan Baru (New Normal). Kegiatan KKN (Kuliah Kerja Nyata) dengan melakukan edukasi pemahaman dan berkontribusi dalam pelaksanaan penanggulangan COVID-19 melalui protokol kesehatan yang ada.

Berdasarkan latar belakang masalah diatas, maka pengabdi tertarik untuk melakukan KKN dengan melakukan edukasi di masyarakat Desa Kedungrukem Kecamatan Benjeng Kabupaten Gresik dalam melakukan penanggulangan COVID-19 melalui program edukasi bahaya, pencegahan penyebaran dan penularan serta pentingnya menabung dimasa pandemi COVID-19. 


\section{DedikasiMU (Journal of Community Service)}

Volume 3, Nomor 3, September 2021

Dalam menunjukkan bahaya dan mencegah penularan dan penyebaran COVID-19 ini, saya mengedukasi masyarakat melalui pemberian pemahaman tentang COVID-19 secara online tentang pentingnya penggunaan masker saat berpergian, pentingnya memakai handsanitizer saat berada di luar rumah dan pentingnya mencuci tangan yang benar. Selain itu, dalam program edukasi tentang pentingnya menabung dimasa Pandemi ini, saya menggunakan video yang menjelaskan tentang pentingnya menabung dan keuntungan menabung dimasa Pandemi COVID19 ini, saya juga membuat pembukuan laporan keuangan untuk Karang Taruna Dusun Bulak Ploso. Maka dari itu, artikel ini membahas mengenai kegiatan KKN di Desa Kedungrukem melalui edukasi kepada masyarakat serta pemahaman mengenai pentingnya mengikuti aturan protocol kesehatan dalam penanggulangan COVID-19 dan pentingnya menghemat dimasa Pandemi COVID19.

\section{METODE PENELITIAN}

\section{Onlineisasi}

Menyampaikan maksud dan tujuan kegiatan dalam bentuk Kegiatan Edukasi secara Online terkait Virus COVID19, Pentingnya menabung dimasa pandemi, dan kegiatan pembukuan Karang Taruna. Selain kegiatan pembukuan Karang Taruna, seluruh edukasi tersebut ditujukan kepada seluruh masyarakat Kedungrukem Kecamatan Benjeng Kabupaten Gresik.

Selain itu, masyarakat juga diberikan motivasi agar memiliki kemauan untuk selalu menjaga kesehatan agar terhindar dari COVID19, kemauan untuk selalu mengedepankan kebutuhan daripada keingininan, dan juga memotivasi seluruh anggota Karang Taruna Bina Muda agar selalu melaporkan setiap transaksi keluar masuknya kas.

\section{Perencanaan Kegiatan}

Perencaaan kegiatan dapat dilakukan setelah pelaksanaan onlineisasi dilakukan. Program KKN dilakukan dengan menerapkan protokol pemerintah yaitu work from home dan social distancing (Nurhalimah 2020). Adapun program yang akan dilakukan yaitu Edukasi Masyarakat terhadap bahaya dan cara pencegahan COVID-19. KKN dilakukan pada bulan Juni-Juli 2020. 


\section{DedikasiMU (Journal of Community Service)}

Volume 3, Nomor 3, September 2021

\section{Pelaksanaan}

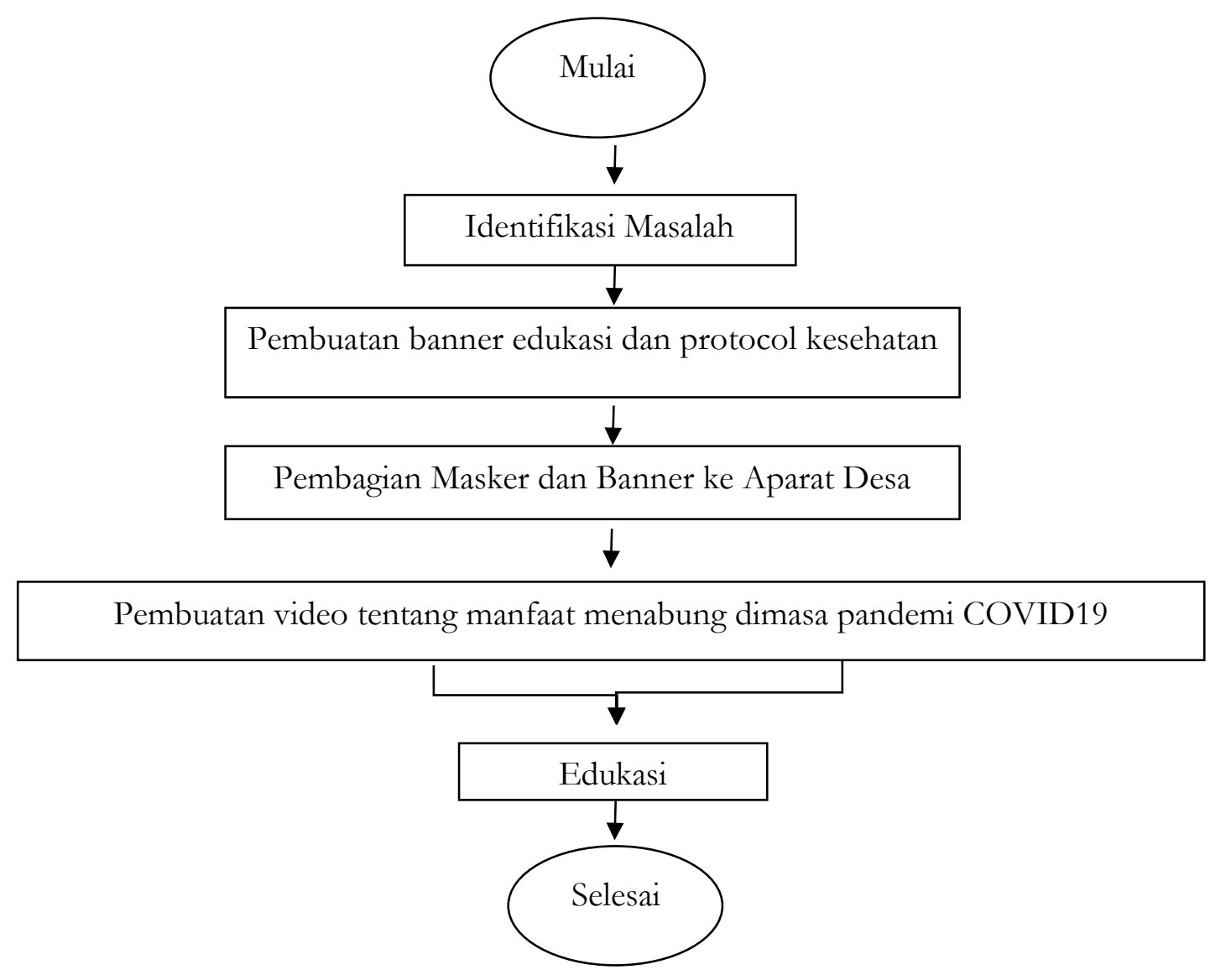

Gambar 1. Alur Kegiatan

4. Monitoring dan Evaluasi

Dari latar belakang masalah yang ada, program KKN yang dilakukan berdasarkan kalsifikasi yang terdapat pada Tabel 1 . 


\section{DedikasiMU (Journal of Community Service)}

Volume 3, Nomor 3, September 2021

Tabel 1. Identfikasi Permasalahan Masyarakat

\begin{tabular}{|c|c|c|c|}
\hline No & Masalah & Alternatif Pemecahan & Bentuk Kegiatan \\
\hline 1. & $\begin{array}{c}\text { Pemahaman } \\
\text { masyarakat terhadap } \\
\text { covid-19 masih } \\
\text { rendah }\end{array}$ & $\begin{array}{c}\text { Memberikan edukasi tentang } \\
\text { covid-19 dan cara-cara } \\
\text { pencegahan }\end{array}$ & $\begin{array}{l}\text { Melakukan pembuatan banner } \\
\text { edukasi, video tentang covid19 } \\
\text { yang kemudian dibagikan pada } \\
\text { Aparat Desa Kedungrukem yang } \\
\text { selanjutnya disalurkan oleh } \\
\text { Aparat Desa kepada warga dan } \\
\text { disebarkan di youtube. }\end{array}$ \\
\hline 2. & $\begin{array}{c}\text { Penggunaan } \\
\text { protokol kesehatan } \\
\text { saat beraktivitas di } \\
\text { luar rumah masih } \\
\text { jarang dilakukan. }\end{array}$ & $\begin{array}{c}\text { Memberikan edukasi } \\
\text { pentingnya penggunaan } \\
\text { protokol kesehatan di tengah } \\
\text { pandemi covid-19 serta } \\
\text { mengedukasi langkah- } \\
\text { langkah penggunaan } \\
\text { protokol kesehatan yang } \\
\text { benar. }\end{array}$ & $\begin{array}{l}\text { Membuat edukasi penggunaan } \\
\text { masker kain, handsanitizer, dan } \\
\text { disinfektan. }\end{array}$ \\
\hline 3. & $\begin{array}{c}\text { Pemahaman } \\
\text { mengenai } \\
\text { pendahuluan } \\
\text { kebutuhan daripada } \\
\text { keinginan dimasa } \\
\text { Pandemi Covid19. }\end{array}$ & $\begin{array}{l}\text { Memberikan edukasi tentang } \\
\text { pentingnya menabung di } \\
\text { tengah pandemi covid19. }\end{array}$ & $\begin{array}{c}\text { Membuat video edukasi tentang } \\
\text { manfaat menabung yang } \\
\text { ditujukan ke anak-anak agar } \\
\text { mereka lebih bisa menghargai } \\
\text { uang yang diberikan leh orangtua } \\
\text { mereka. }\end{array}$ \\
\hline 4. & $\begin{array}{c}\text { Pemahaman } \\
\text { Pembuatan } \\
\text { pembukuan laporan } \\
\text { keuangan karang } \\
\text { taruna di Dusun } \\
\text { Bulak Ploso }\end{array}$ & $\begin{array}{l}\text { Memberikan pemahaman } \\
\text { tentang langkah-langkah } \\
\text { membuat pembukuan } \\
\text { laporan keuangan. }\end{array}$ & $\begin{array}{l}\text { Memberikan contoh pembuatan } \\
\text { pembukuan laporan keuangan } \\
\text { Karang Taruna Dusun Bulak } \\
\text { Ploso. }\end{array}$ \\
\hline
\end{tabular}




\section{DedikasiMU (Journal of Community Service)}

Volume 3, Nomor 3, September 2021

Hasil yang dicapai yakni respon dari masyarakat Desa Kedungrukem baik, banyak masyarakat yang menonton video yang saya bagikan di youtube dan mereka juga mau mencoba untuk mengaplikasikan di kehidupan sehari-hari.

\section{HASIL DAN PEMBAHASAN}

\section{A. Edukasi}

Edukasi dilakukan agar masyarakat mengetahui tata cara penanggulangan COVID-19 (Sulaeman, dkk 2020). Pada KKN ini edukasi berfokus pada masyarakat Desa Kedungrukem, Kecamatan Benjeng, Kabupaten Gresik. Edukasi yang dilakukan tetap menerapkan sistem social distancing yaitu sosialisasi menggunakan sosial media, poster, banner dan video. Sosialisai berfokus pada penggunaan alat protokol kesehatan yaitu masker dan handsanitizer. Masyarakat diberikan penjelasan mengenai pemahaman berdasarkan sumber terpercaya, sehingga masyarakat mendapatkan informasi yang bisa diterapkan pada keseharian. Berikut merupakan edukasi yang dilakukan:

\section{a. Edukasi COVID-19 melalui Sosial Media}

Berpedoman pada WHO (World Health Organization), saya menyebarkan edukasi covid-19 melalui sosial media. Tujuannya tentu terutama demi menyebarluaskan pengetahuan tentang penanganan dan pencegahan penyebaran Covid-19. Adapun media sosial yang digunakan adalah Facebook, Instagram, dan Youtube.

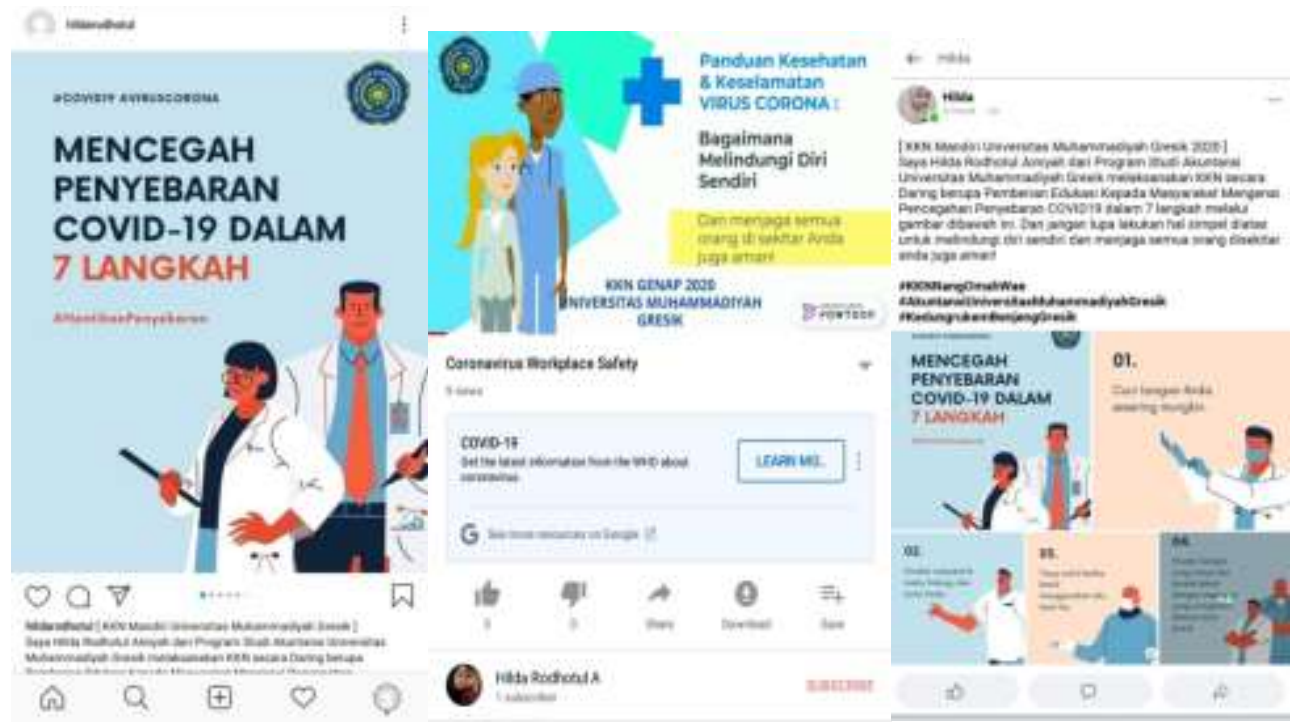

Gambar 2. Edukasi Pencegahan Penularan COVID19 Melalui Instagram, Youtube dan Facebook. 


\section{DedikasiMU (Journal of Community Service)}

Volume 3, Nomor 3, September 2021

\section{b. Edukasi Cara Menggunakan Masker dan Selalu Berjaga Jarak melalui Poster}

Di tengah pademi covid-19, masyarakat masih sering salah dalam menggunakan masker. Seringkali masker digunakan dibawah hidung dan masih banyaknya masyarakat yang sering bergerombol, padahal berjaga jarak disaat pandemi merupakan salah satu pencegahan penularan covid19. Oleh karena itu, saya memberikan poster edukasi cara penggunaan masker dan poster mengingatkan agar selalu berjaga jarak dimasa covid-19 yang dibagikan ke Aparat Desa yang selanjutnya disalurkan oleh Aparat Desa ke tiap-tiap rumah.

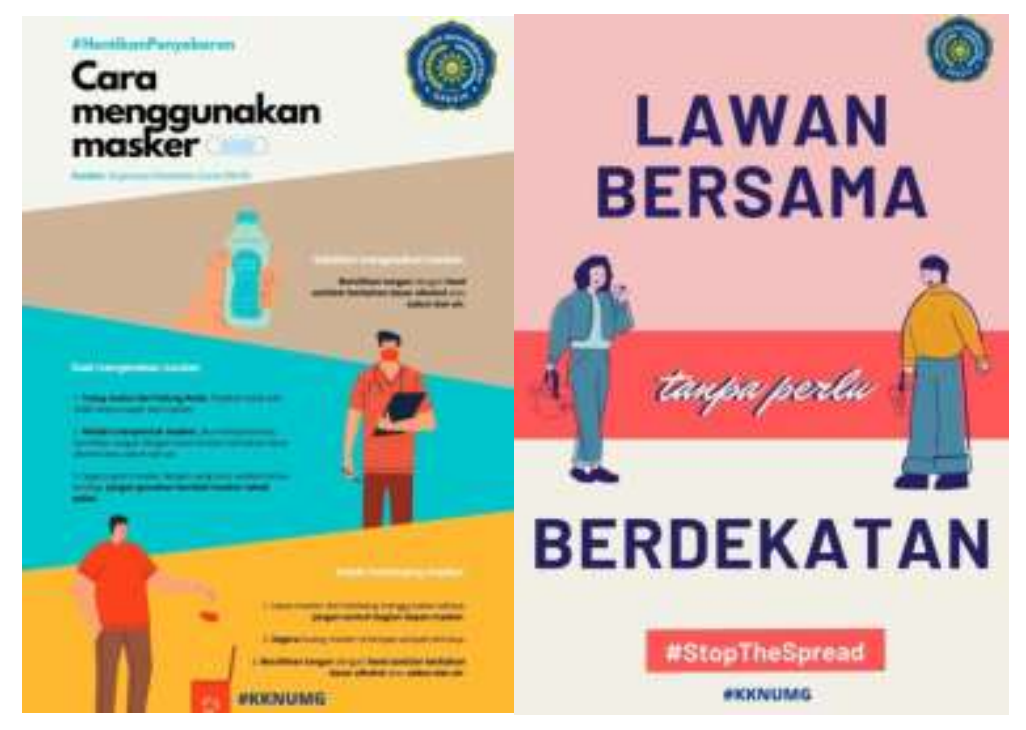

Gambar 3. Cara penggunaan masker dan himbauan untuk berjaga jarak melalui poster

\section{c. Edukasi COVID-19 melalui Banner}

Pada bulan Juni 2020, pemerintah membuat kebijakan baru (New Normal). Dalam rangka mendukung kebijakan tersebut, saya memberikan edukasi tentang gejala \& pencegahan covid-19 melalui banner yang dipasang di Balaidesa Kedungrukem agar masyarakat tetap mematuhi protokol kesehatan meskipun telah menjalankan kebijakan New Normal. 


\section{DedikasiMU (Journal of Community Service)}

Volume 3, Nomor 3, September 2021

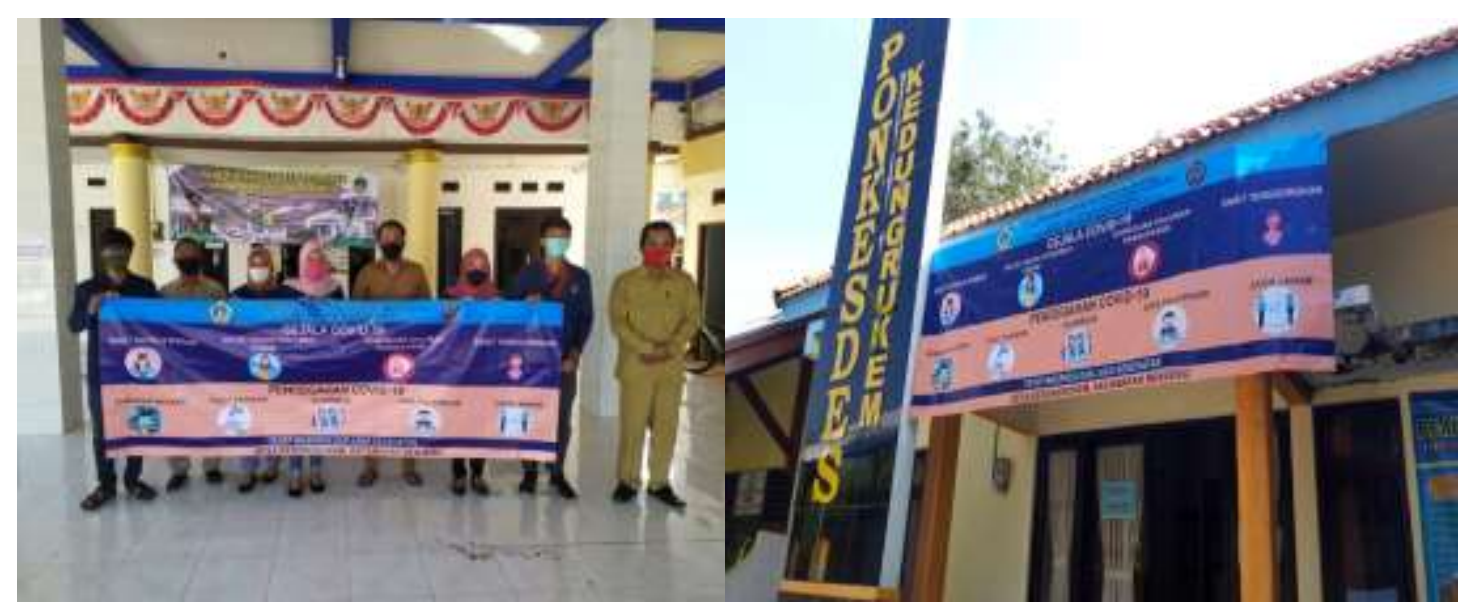

Gambar 4. Edukasi Gejala \& Pencegahan Covid-19 melalui banner

\section{d. Edukasi Pentingnya Menabung Dimasa Pandemi COVID19}

Mayoritas kalangan anak-anak masih sering menggunakan uang jajan mereka untuk memenuhi keinginannya. Padahal disaat Pandemi covid19 saat ini perekonomian sedang surut-surutnya. Maka dari itu, saya memberikan edukasi berupa video yang saya publikasikan ke youtube mengenai pentingnya mendahulukan kebutuhan dan menyisihkan uang jajan untuk ditabung ditengah pandemi covid 19.

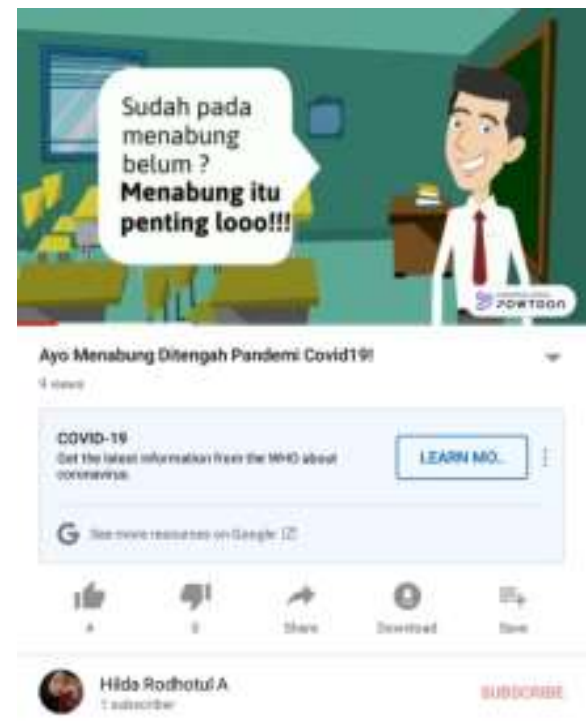

Gambar 5. Edukasi Pentingnya menabung ditengah Covid19 melalui video 


\section{DedikasiMU (Journal of Community Service)}

Volume 3, Nomor 3, September 2021

\section{B. Pembuatan Pembukuan Laporan Keuangan Karangtaruna}

Pada Juli 2020, Karangtaruna Bina Muda Dusun Bulak Ploso melakukan pembukuan Triwulan II. Saya membuatkan laporan keuangan sederhana yang sudah saja pelajari di Program Studi Akuntansi Universitas Muhammadiyah Gresik. Dengan saya membuat laporan keuangan ini, saya berharap untuk selanjutnya Bendahara Karangtaruna Bina Muda dalam membuat laporan keuangan lebih terstruktur.

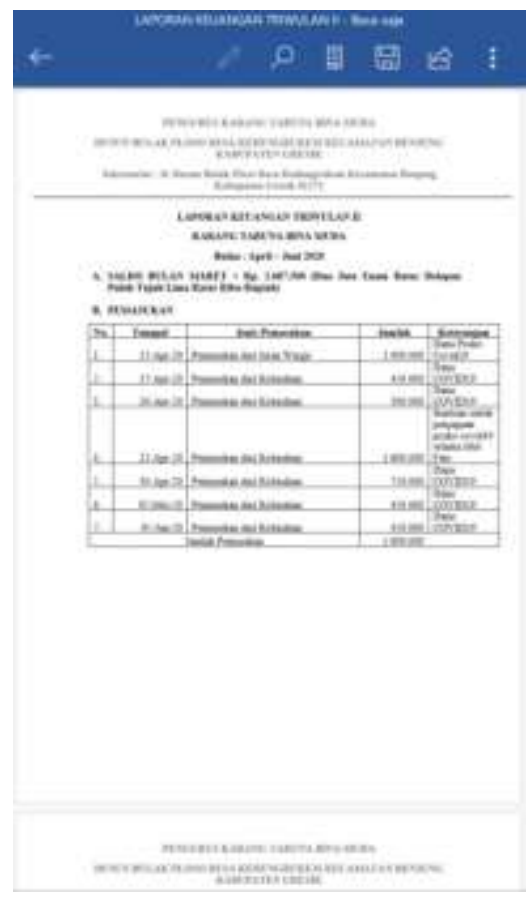

Gambar 6. Laporan keuangan Karangtaruna

\section{Penyaluran Protokol Kesehatan Kepada Masyarakat}

Produk masker kain kemudian akan diberikan kepada Aparat Desa yang kemudian disalurkan ke masyarakat sebagai protokol kesehatan yang perlu digunakan di tengah pandemi covid-19. Jumlah masker kain yang dibagikan adalah 75 masker. Diharapkan dengan pembagian protokol kesehatan ini masyarakat Desa Kedungrukem Kecamatan Benjeng Kabupaten Gresik lebih mematuhi aturan pemerintah dan agar kesehatan masyarakat selalu terjaga. 


\section{DedikasiMU (Journal of Community Service)}

Volume 3, Nomor 3, September 2021
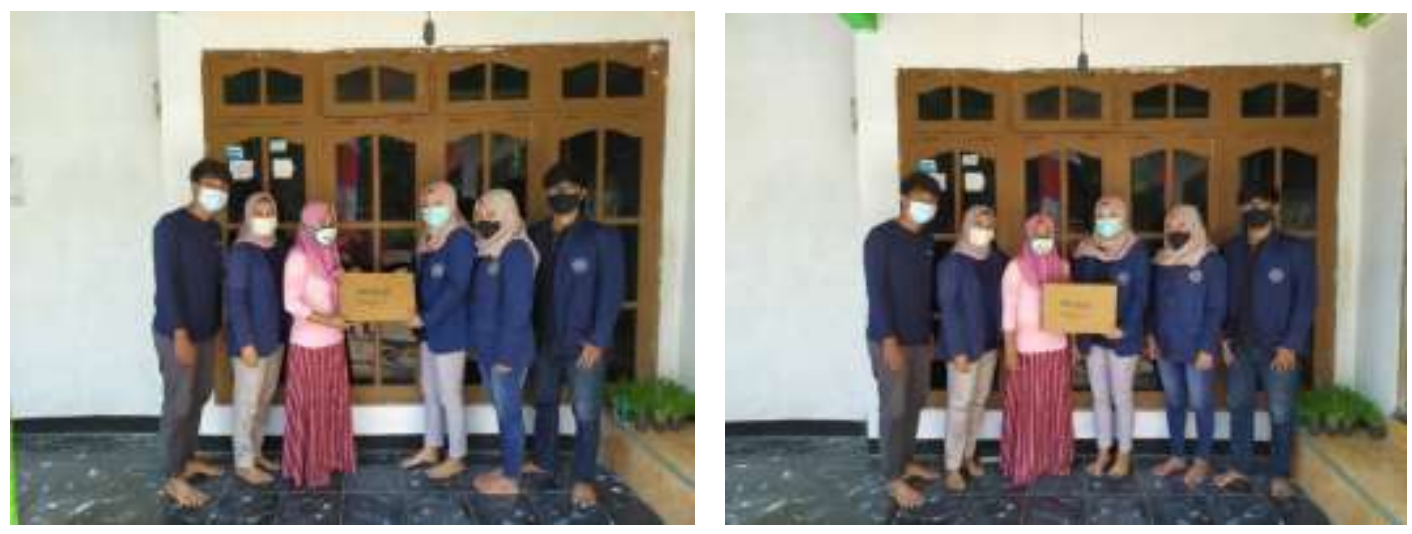

Gambar 7. Penyaluran masker

\section{KESIMPULAN DAN SARAN}

Kegiatan KKN di lingkungan Desa Kedungrukem Kecamatan Benjeng Kabupaten Gresik selama bulan Juli-Agustus 2020 telah berhasil dilakukan. Kegiatan dilakukan untuk memberikan Edukasi mengenai pencegahan COVID-19 dan pentingnya penggunaan protokol kesehatan guna menanggulangi COVID-19. Untuk menunjang pencegahan COVID-19, telah diproduksi masker dan handsanitizer yang dapat digunakan oleh masyarakat. Masker yang dibuat adalah masker kain 2 ply 2 lapis dan handsanitizer mengandung $70 \%$ alcohol. Kegiatan lain yang dilakukan adalah edukasi tentang pentingnya mendahulukan kebutuhan dan menyisihkan sebagian uang untuk ditabung dimasa Pandemi Covid19 serta Pembuatan Laporan Keuangan Triwulan untuk Karangtaruna Bina Muda Dusun Bulak Ploso. Sebagai bentuk peningkatan pemahaman penanggulangan COVID-19 di Desa Kedungrukem telah dilakukan edukasi melalui sosial media, poster, banner, dan video. Edukasi dengan sistem tersebut dilakukan sebagai salah satu bentuk penerapan protokol work from home dan social distancing. Edukasi dimaksudkan agar masyarakat paham mengenai pentingnya pengguaan protokol kesehatan saat melakukan aktivitas di luar rumah. 


\section{DedikasiMU (Journal of Community Service)}

Volume 3, Nomor 3, September 2021

\section{DAFTAR PUSTAKA}

Al Fatina, A., Rochma, N. A., Salsabilah, N., Sari, C. S., Rahma, A., Fauziyah, N., Sukaris, S \& Rahim, A. R. (2021). Pemberdayaan Para Pemuda Dalam Pemanfaatan Tanaman Obat Keluarga (Toga) Temulawak (Curcuma Xanthorhiza) Menjadi Olahan Ice Cream Di Desa Sambogunung. DedikasiMU (Journal of Community Service), 3(2), 801-810.

Al Fatina, A., Rochma, N. A., Salsabilah, N., Eprilyanto, A. F., Aulia, R., Sukaris, S., Fauziyah, N \& Rahim, A. R. (2021). Pembuatan Minyak Sereh Dan Lilin Aromaterapi Sebagai Anti Nyamuk. DedikasiMU (Journal of Community Service), $3(2), 837-847$.

Darmalaksana, W., Hambali, R., Masrur, A., \& Muhlas, M. (2020). Analisis Pembelajaran Online Masa WFH Pandemic Covid-19 sebagai Tantangan Pemimpin Digital Abad 21. Karya Tulis Ilmiah (KTI) Masa Work From Home (WFH) Covid-19 UIN Sunan Gunung Djati Bandung, 1-12.

Guan, W. J., Ni, Z. Y., Hu, Y., Liang, W. H., Ou, C. Q., He, J. X., ... \& Du, B. (2020). Clinical characteristics of coronavirus disease 2019 in China. New England journal of medicine, 382(18), 1708-1720.

Hayes, A. (2018). U.S. Patent No. 9,894,952. Washington, DC: U.S. Patent and Trademark Office.

Hutagalung, P. (2020). Makalah Penjasorkes tentang Penyakit Virus Corona.

Kemendikbud. (2020) 'Perluas Akses Belajar di Masa Covid-19, Mendikbud Luncurkan Program Belajar dari Rumah' Kementerian Pendidikan dan Kebudayaan. [online]. Tersedia di: https://www.kemdikbud.go.id/main/blog/2020/04/perluasakses-belajar-di-masa-covid19-mendikbud-luncurkan-program-belajar-dari-rumah Diakses: 13 April 2020

Kemendesa. (2020). Protokol Relawan Desa Lawan COVID-19. Jakarta: Kementerian Desa, Pembangunan Daerah Tertinggal, dan Transmigrasi.

Khaeruman, B., Nur, S., Mujiyo, M., \& Rodliyana, D. (2020). Pandemi Covid-19 dan kondisi darurat: Kajian hadis tematik. UIN Sunan Gunung Djati Bandung. 


\section{DedikasiMU (Journal of Community Service)}

Volume 3, Nomor 3, September 2021

MUI. (2020). Fatwa Majelis Ulama Indonesia Nomor: 14 Tahun 2020 Tentang Penyelenggaran Ibadah Dalam Situasi Terjadi Wabah Covid-19. Jakarta: Komisi Fatwa Majelis Ulama Indonesia.

Muhyiddin, A., Rosyad, R., Rahman, M. T., \& Huriani, Y. (2020). Urgensi penjelasan keagamaan terhadap keluarga suspek Pasien Dalam Pengawasan (PDP) Covid19. Karya Tulis Ilmiah UIN SGD Bandung, 1-12.

Nurhalimah, N. (2020). Upaya Bela Negara Melalui Sosial Distancing Dan Lockdown Untuk Mengatasi Wabah Covid-19 (Efforts to Defend the Country Through Social Distancing and Lockdown to Overcome the COVID-19 Plague). Available at SSRN 3576405.

Presiden RI. (2020) Keputusan Presiden Republik Indonesia Nomor 12 Tahun 2020 Tentang Penetapan Bencana Nonalam Penyebaran Corona Virus Disease 2019 (Covid-19) Sebagai Bencana Nasional Jakarta: Kementerian Sekretariat Negara Republik Indonesia. SK No $010750 \mathrm{~A}$

Shodiqin, A., Aziz, R., Dewi, R., \& Fitriani, P. D. (2020) Model pemberdayaan jama'ah masjid menghadapi dampak coronavirus disease (covid 19).

Sulaeman, S., \& Supriadi, S. (2020). Peningkatan Pengetahuan Masyarakat Desa Jelantik Dalam Menghadapi Pandemi Corona Virus Diseases-19 (Covid-19). Jurnal Pengabdian UNDIKMA, 1(1).

Telaumbanua, D. (2020). Urgensi Pembentukan Aturan Terkait Pencegahan Covid-19 Di Indonesia. QALAMUNA: Jurnal Pendidikan, Sosial, dan Agama, 12(01), 59-70.

Wasson, B. C., Shealy, A. W., \& Conner, J. E. (2017). U.S. Patent No. 9,795,346. Washington, DC: U.S. Patent and Trademark Office.

WHO. (2020) 'WHO announces COVID-19 outbreak a pandemic' World Health Organzation Regional Office for Europe. [online] Tersedia di: http://www.who.int/en/health-topics/health-emergencies/coronavirus-covid19/news/news/2020/3/who-announces-covid-19-outbreak-a-pandemic Diakses: 6 Mei 2020. 